\title{
The Approach of Accounting Information Quality on Investment Efficiency-Empirical Evidence from Chinese Listed Companies
}

\author{
Chunyan Ren \\ Management School of Xiamen University, Xiamen, China \\ Email:cyren@xmu.edu.cn
}

Received 29 March 2016; accepted 25 April 2016; published 28 April 2016

Copyright (C) 2016 by author and Scientific Research Publishing Inc.

This work is licensed under the Creative Commons Attribution International License (CC BY). http://creativecommons.org/licenses/by/4.0/

(c) (i) Open Access

\begin{abstract}
This paper studies the approach of accounting information quality on investment efficiency, from the context of the Chinese reality system. The empirical results confirm that the proxy for accounting information quality is negatively associated with over-investment or under-investment. Furthermore, there is a negative association between the quality of accounting information and the future investment for firms classified as over-investment and a positive association between the quality of accounting information and the future investment for firms classified as underinvestment. The results suggest that the improvement of accounting information quality helps to restrict companies from over-investment and helps the companies to mitigate under-investment.
\end{abstract}

\section{Keywords}

Accounting Information Quality, Investment Efficiency, Over-Investment, Under-Investment

\section{Literatures Review and Hypothesis Development}

The so-called investment efficiency, is that a firm undertakes all and only projects with positive Net Present Value (NPV) under the scenario of no market frictions such as adverse selection or agency costs [1]. Accordingly, investment inefficiency includes undertaking (passing up) projects with negative (positive) NPV [2].

Under ideal conditions, corporate undertakes and only undertakes projects with positive net present value; Tobin's Q or marginal Tobin's Q which represents growth and development opportunities is the only driving factor of corporate investment policy [3]-[5]. However, the capital market is not perfect; the problem of adverse selection and moral hazard may make the company deviate from the optimal investment level and in the underinvestment or over-investment risk, which affects the investment efficiency [6]. 
Prior studies suggest that higher-quality accounting information can enhance investment efficiency by mitigating information asymmetries that cause economic frictions such as moral hazard and adverse selection [7] [8].

First, it is commonly argued that accounting information mitigates adverse selection costs by reducing the information asymmetry between the firm and investors, and among investors which lower the firm's cost of raising funds; second, it is well established that accounting information is used by shareholders to monitor manager thus it can be associated with investment efficiency by reducing moral hazard. Figure 1 illustrates the relationship between the accounting information quality and the capital investment efficiency.

Sun [9] studied the efficiency of capital investment and financial reporting relationship on a sample of 23 countries. The results show that high-quality financial reporting will help improve efficiency of capital allocation especially for the equity financing business.

Biddle, Hilary and Verdi [1] studied the relation between accounting information quality and investment efficiency. They find that the proxies for accounting information quality are negatively associated with both firm under-investment and over-investment. Further, their studies provide evidence in documenting a conditional negative (positive) association between accounting information quality and investment for firms operating in settings more prone to over-investment (under-investment). Firms with higher accounting information quality also are found to deviate less from predicted investment levels and show less sensitivity to macro-economic conditions. These results suggest that one mechanism linking reporting quality and investment efficiency is a reduction of frictions such as moral hazard and adverse selection that hamper efficient investment.

Cheng, Dhaliwal and Zhang [10] provided more direct evidence on the causal relation between the quality of financial reporting and investment efficiency. They examine the investment behavior of a sample of firms that disclosed internal control weaknesses under the Sarbanes-Oxley Act. They find that prior to the disclosure, these firms under-invest (over-invest) when they are financially constrained (unconstrained). More importantly, they find that after the disclosure, these firms' investment efficiency improves significantly.

Juan, Beatriz and Fernando [11] argued that conservatism improves investment efficiency. In particular, they predict that it resolves debt-equity conflicts, facilitating a firm's access to debt financing and limiting underinvestment. Their empirical results confirm these predictions. They find that more conservative firms invest more and issue more debt in settings prone to under-investment and that these effects are more pronounced in

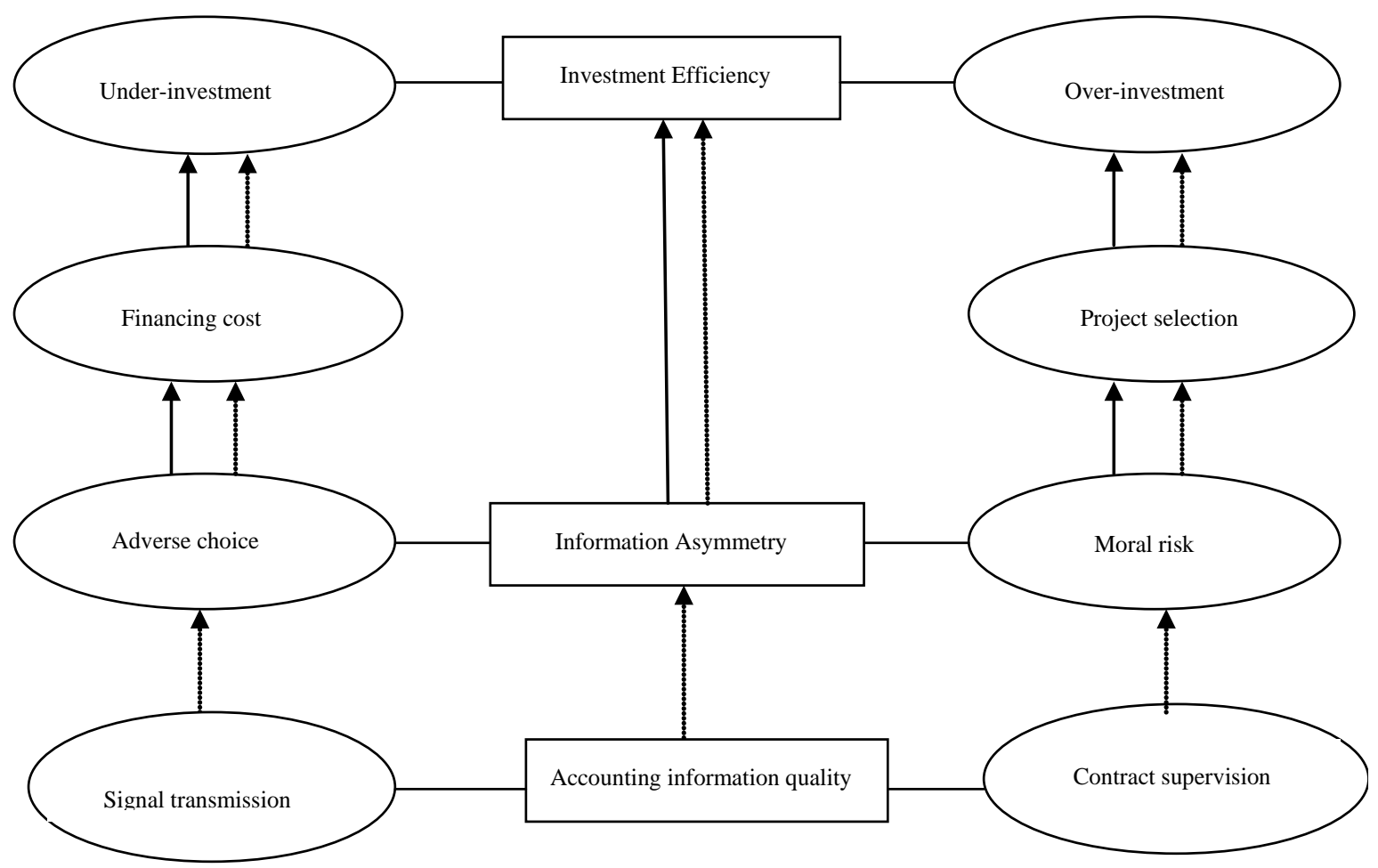

Figure 1. Accounting information on quality and firm investment efficiency. 
firms characterized by greater information asymmetries. They also find that conservatism is associated with reduced over-investment, even for opaque investments such as research and development.

Based on the discussion above, I hypothesize that high accounting information quality is negatively associated with over-investment or under-investment; the improvement of accounting information quality helps to restrict companies from over-investment and helps the companies to mitigate under-investment.

H1: Accounting information quality is negatively associated with under-investment or over-investment.

H2: For under-investment firms, the accounting information quality is positively related to the firm's future investment, that is, the improvement of the accounting information quality can alleviate the under-investment of the firm.

H3: For over-investment firms, the accounting information quality is negatively related to the firm's future investment, that is, the improvement of the accounting information quality can reduce the over-investment of the firm.

H4: For firms prone to under-investment (or over-investment), the improvement of the accounting information quality can weak the tendency of under-investment (or over-investment) caused by the financial constrains or free cash flow.

\section{Research Design}

\subsection{Proxy for Investment Efficiency}

In order to measure investment efficiency, the paper use the model of Richardson [12] that predicts firm investment levels and then use residuals from this model as a proxy for inefficient investment. The greater the absolute value of residuals, the lower investment efficiency is. Specially I estimate the following model:

$$
\begin{aligned}
\text { Inv }_{i, t}= & \beta_{0}+\beta_{1} \text { Salesgrows }_{i, t-1}+\beta_{2} \text { Leverage }_{t-1}+\beta_{3} \text { Cash }_{t-1}+\beta_{4} \text { Age }_{t-1}+\beta_{5} \text { Size }_{t-1} \\
& +\beta_{6} \text { Stock Return }_{t-1}+\beta_{7} \text { Inv }_{i, t-1}+\beta_{8} \sum \text { Year Indicator }+\beta_{9} \sum \text { Industry Indicator }+\varepsilon_{i, t}
\end{aligned}
$$

where $\operatorname{Inv}_{i, t}$ is the total investment expenditure calculated as the sum of fixed assets expenditure, intangible expenditure and other long-term assets expenditure, multiplied by 100 and scaled by average total assets. In the sensitivity section we also discuss the robustness of the result to the use of an alternative proxy for investment that is frequently used in the literature.

Salesgrows $_{i, t-1}$ is a measure of growth opportunities and calculated as the ratio of Sales growth. Leverage ${ }_{i, t-1}$ is the company's financial leverage, equal to the liabilities over total assets; Cash ${ }_{i, t-1}$ is the balance of cash and short term investments deflated by total assets measured at the start of the year. Age itt-1 $_{1}$ is the number of years the firm has been listed as of the start of the year. Size ${ }_{i, t-1}$ is the log of total assets measured at the start of the year. Stock Return ${ }_{i, t-1}$ is the stock return for the year prior to the investment year. Year Indicator is a vector of indicator variable to capture annual fixed effects and Industry Indicator is a vector of indicator variable to capture industry fixed effects.

\subsection{Proxy for Quality of Financial Reporting}

The concept definition of accounting information quality used is the accuracy with which financial reporting conveys information about the firm's operations, in particular its expected cash flows, in order to inform investors in terms of equity investment decisions [1]. The paper proxy for accounting information quality using measures of accruals quality based on the idea that accruals are estimates of future cash flows, and earnings will be more representative of future cash flows when there is lower estimation error embedded in the accruals process [13] [14]. The paper proxy for accounting information quality using measures of accruals derived in model [13]. The model is described below:

$$
\Delta \mathrm{WC}_{i, t}=\alpha_{0}+\alpha_{1} \mathrm{CFO}_{i, t-1}+\alpha_{2} \mathrm{CFO}_{i, t}+\alpha_{3} \mathrm{CFO}_{i, t+1}+\varepsilon_{i, t}
$$

In model (2), $\Delta \mathrm{WC}_{i, t}$ represents working capital, where $\Delta \mathrm{WC}_{i, t}=$ ( $\Delta$ accounts receivable $+\Delta$ inventory $)-$ ( $\Delta$ account payable $+\Delta$ tax payable); $\mathrm{CFO}_{i, t-1}, \mathrm{CFO}_{i, t}, \mathrm{CFO}_{i, t+1}$ are cash flows of lagged, current and future. All variables are scaled by average total assets. The prediction error, $\varepsilon_{i, t}$ represents the level of discretionary accruals (AQ). The higher the discretionary accruals, indicating that the quality of financial reporting of listed companies lower. We multiply by negative one so that $\mathrm{AQ}$ is increasing in accounting information quality. 


\subsection{Research Design}

In this paper, I use the method of multiple regression analysis to study the relationship between investment efficiency and quality of financial reporting of listed companies in China. In particular, I estimate the following model.

$$
\begin{aligned}
\text { Nginv }_{i, t}= & \gamma_{0}+\gamma_{1} \mathrm{AQ}_{i, t-1}+\gamma_{2} \mathrm{ROA}_{i, t-1}+\gamma_{3} \mathrm{SAR}_{i, t-1}+\gamma_{4} \text { Institutions }_{i, t-1}+\gamma_{5} \text { Cont }_{i, t-1} \\
& +\gamma_{6} \mathrm{Sh}_{i, t-1}+\gamma_{7} \sum \text { Year Indicator }+\gamma_{8} \sum \text { Industry Indicator }+\varepsilon_{i, t}
\end{aligned}
$$

In model (3), Nginv $_{i, t}$ is the absolute value of the residuals from the model (1), it is a proxy for underinvestment or over-investment. $\mathrm{AQ}_{i, t}$ is defined as the discretionary accruals from the model (2). I multiply it by negative one so that $\mathrm{AQ}$ at year $\mathrm{t}$ is increasing in accounting information quality.

I also introduce controls for effects that could confound the findings. First, I control for the ratio of return on assets (ROA), in order to distinguish between the number of earnings and quality of earnings. Second, I control for the ratio of annual sales to total assets (SAR), Ang et al. [15] suggest that the level of SAR reflects the extent of effective to which management use the assets of enterprise, so SAR can be a representative of enterprise efficiency.

China listed companies has two significant features. First, most of them are stated-owned companies; second, the Concentration of ownership is very high. So I control for the dumb variable Cont, If the company is a stateowned company, then Cont $=1$, otherwise Cont $=0$. I also control for the top 1 shareholder (Sh1), which can be a representative of the ownership concentration. Ferreira and Mators [16] find that companies with more institutional investors have low capital cost, suggesting that institutional investors can curb excessive investment, so I control for the proportion of the share held by institutions investors (Institution).

To investigate hypotheses 2 and 3, and use Richardson [12], Biddle, Hilary and Verdi [1], I divided the sample into over-investment and under-investment firms. Over-investment is the positive residuals of the investment model and under-investment is the negative residuals of the investment model. In this sample, there are 1599 (2910) firms classified as over-investment (under-investment) firms.

$$
\begin{aligned}
\operatorname{Inv}_{i, t}= & \varphi_{0}+\varphi_{1} A Q_{i, t-1}+\varphi_{2} \text { Salesgrow }_{i, t-1}+\varphi_{3} \text { Salesgrow }_{i, t-1}+\varphi_{4} \text { Age }_{i, t-1}+\varphi_{5} \text { Institutions }_{i, t-1} \\
& +\varphi_{6} \text { Cont }_{i, t-1}+\varphi_{7} \text { Sh1 }_{i, t-1}+\varphi_{8} \sum \text { Year Indicator }+\varphi_{9} \sum \text { Industry Indicator }+\varepsilon_{i, t-1}
\end{aligned}
$$

In model (4), $\operatorname{Inv}_{i, t}$ is the firm's new investment expenditure at the year $t$, calculated as the sum of fixed assets expenditure, intangible expenditure and other long-term assets expenditure, multiplied by 100 and scaled by average total assets. Dependent variable AQ is the accounting information quality defined as the discretionary accruals from the model (2). Control variables are defined as before.

Hypothesis 4 studies whether the quality of accounting information can weaken the tendency of over-investment or under-investment caused by the firm's free cash flow or financing constraints. To investigate hypothesis 4, I introduce the characteristic variable Partition which represents the investment tendency of the company, to examine the relationship between the quality of accounting information and the investment efficiency when the company has the tendency of under-investment or over-investment. Specially I estimate the following model:

$$
\operatorname{Inv}_{i, t}=\rho_{0}+\rho_{1} \mathrm{AQ}+\rho_{2} \times \text { Partition }_{i, t-1}+\rho_{3} \text { Partition }_{i, t-1}+\rho_{4} \text { Controls }_{i, t-1}+\varepsilon_{i, t}
$$

In model (5), Partition is an index reflects the firm's investment tendency caused by the free cash flow or financing constraints. It is calculated as follow: I sort the firm's cash balance and debt ratio (debt ratio multiplied by -1 ) and value them from 0 to 1 , the mean value of the two variables is the Partition. Partition increases represents the firm prone to over-investment; Partition decreases represents the firm prone to under-investment. $\rho_{1}$ measures the relationship between the accounting information quality and the under-investment tendency of company (that is, with the lowest cash balance and the highest debt ratio), according to the hypothesis, $\rho_{1}>0$; $\rho_{1}$ $+\rho_{2}$ measures the relationship between the accounting information quality and the over-investment tendency of company (that is, with the highest cash balance and the lowest debt ratio), according to the hypothesis, $\rho_{1}+\rho_{2}<$ 0 . Control variables are defined as model (4).

\section{Main Empirical Results}

\subsection{Sample and Descriptive Statistics}

The study sample consists of 4509 firm-year observations from 2005 to 2009 in Shanghai and Shenzhen Stock 
Exchange. I collect financial reporting data from CSMAR. Consist with previous practice in the references, financial firms are excluded because of the different nature of investment for the firms. In order to mitigate the influence of outliers, I winsorize all continuous variables at the $1 \%$ and $99 \%$ levels by year at the firm-year level.

Table 1 presents descriptive statistics for the variables described above. The mean (median) value for Inv is $0.056(0.032 \%)$, the mean value of companies' investment expenditure from 1993-2005 in the U.S. calculated by Biddle, Hilary and Verdi [2] with the same index calculation is 0.141 , In contrast, the investment expenditure of Chinese listed companies is much smaller. The mean value is much bigger than the median value, it shows a significant difference in different company's investment expenditure.

Table 2 presents Pearson correlations between the main variables. We can see that the investment expenditure (Inv) and the accounting information quality are significantly related, and the Inv is significantly related to the firm characteristics (Institutions, Cont and Sh1). These results present preliminary evidence for the relation between accounting information quality and investment efficiency in hypotheses 1.

\subsection{Multiple Regressions}

Table 3 presents the results of multiple regressions of Model (3). The estimated model is a regression of investment efficiency on accounting information quality, firm characteristics and industry and year fixed effects. The independent variable is Nginv which proxy for investment inefficicency. As predicted in hypothesis, Investment Inefficiency is negatively related to AQ (coefficient is significant at $1 \%$ level), that means improve the quality of financial reporting can improve investment efficiency of listed companies.

\begin{tabular}{ccccccc} 
Table 1. Descriptive statistics. & \multicolumn{1}{l}{ Median } & Max & Min & STD \\
\hline OBS & Mean & 0.032 & 0.406 & -0.056 & 0.078 \\
Inv & 4509 & 0.056 & 0.028 & 0.277 & 0.000 & 0.046 \\
Nginv & 4509 & 0.041 & -0.027 & -0.000 & -0.362 & 0.068 \\
AQ & 4509 & -0.051 & 0.021 & 0.223 & -0.384 & 0.082 \\
ROA & 4509 & 0.016 & 0.585 & 3.021 & 0.0250 & 0.560 \\
SAR & 4509 & 0.724 & 0.000 & 0.311 & 0 & 0.056 \\
Institutions & 4509 & 0.021 & 0.337 & 0.852 & 0 & 0.159 \\
Sh1 & 4509 & 0.366 & 1.148 & 4.788 & 0.245 & 0.604 \\
Salesgrow & 4509 & 1.238 & 21.314 & 24.171 & 18.868 & 1.032 \\
Size & 4509 & 21.329 & 10.077 & 16.510 & 5.781 & 2.584 \\
Age & 4509 & 10.268 & & &
\end{tabular}

Table 2. Correlation matrix.

\begin{tabular}{|c|c|c|c|c|c|c|c|c|}
\hline & Inv & $\mathrm{AQ}$ & Salesgrow & Size & Age & Institution & Cont & Sh1 \\
\hline Inv & 1 & & & & & & & \\
\hline $\mathrm{AQ}$ & $0.051^{* * *}$ & 1 & & & & & & \\
\hline Salesgrow & $0.079^{* * *}$ & 0.024 & 1 & & & & & \\
\hline Size & $0.174^{* * *}$ & $0.156^{* * *}$ & $0.077^{* * *}$ & 1 & & & & \\
\hline Age & $-0.067^{* * *}$ & $0.056^{* * *}$ & -0.004 & -0.024 & 1 & & & \\
\hline Institutions & $0.020^{* * *}$ & $-0.067^{* * *}$ & $0.038^{* *}$ & $0.230^{* * *}$ & $-0.036^{* *}$ & 1 & & \\
\hline Cont & $0.094^{* * *}$ & $0.106^{* * *}$ & -0.010 & $0.27^{* * *}$ & -0.007 & $0.077^{* * *}$ & 1 & \\
\hline Sh1 & $0.111^{* * *}$ & 0.016 & $0.072^{* * *}$ & $0.213^{* * *}$ & $-0.219^{* * *}$ & $0.029^{* *}$ & $0.323^{* * *}$ & 1 \\
\hline
\end{tabular}

${ }^{* * *},{ }^{* *}$ and ${ }^{*}$ denote significance at the $1 \%, 5 \%$ and $10 \%$ levels, respectively. 
Table 3. Accounting information quality and investment inefficiency regressions.

\begin{tabular}{|c|c|c|c|c|}
\hline & Coefficient & $\mathrm{T}$ & Coefficient & $\mathrm{T}$ \\
\hline Intercept & $0.033^{* * *}$ & 9.646 & $0.031^{* * *}$ & 8.451 \\
\hline $\mathrm{AQ}$ & $-0.051^{* * *}$ & -4.556 & $-0.050^{* * *}$ & -4.422 \\
\hline ROA & $0.080^{* * *}$ & 9.384 & $0.072^{* * *}$ & 8.146 \\
\hline SAR & $-0.005^{* * *}$ & -3.447 & $-0.005^{* * *}$ & -3.908 \\
\hline Cont & & & -0.002 & -1.252 \\
\hline Sh1 & & & $0.010^{* *}$ & 2.082 \\
\hline Institutions & & & $0.049^{* * *}$ & 3.849 \\
\hline F & \multicolumn{2}{|c|}{14.285} & \multicolumn{2}{|c|}{13.533} \\
\hline Adj- $R^{2}$ & \multicolumn{2}{|c|}{0.074} & \multicolumn{2}{|c|}{0.077} \\
\hline OBS & \multicolumn{2}{|c|}{4509} & \multicolumn{2}{|c|}{4509} \\
\hline
\end{tabular}

The coefficient of ROA is significantly positive, indicating that the higher level of profitability of listed companies, the more likely over-investment problem, which reflects the scale of investment is heavily dependent on its internal cash flow.

SAR coefficient is significantly negative, the ratio of annual sales to total assets is commonly used in empirical research as a measure of corporate agency costs, improve the ratio of annual sales to total assets can reduce agency costs, thereby enhancing investment efficiency.

The estimated coefficient of Institution is significantly positive, the proportion of the share held by institutional investors not reduce but increase the investment inefficiency. Therefore, in our current capital markets, institutional investors could not play an active role in corporate governance.

The coefficient of Cont is negative, but not significant, showed that the investment expenditure of the stateowned or non State-Owned Companies has little difference, which can be explained by the problem of asymmetric information exists in both State-Owned Companies and non State-Owned companies. The sh1 coefficient is significantly positive, indicating that the higher proportion of the top1 shareholder ownership, the lower firm's investment efficiency, the results supports the "tunneling" theory.

Table 4 presents the results of multiple regressions of model (4). In the sample of under-investment companies, AQ regression coefficient is significantly positive, indicating that the accounting information quality is positively related to the company's new capital investment, the results support the hypothesis 3; in the sample of over-investment companies, AQ coefficient is significantly negative, indicating that the accounting information quality is negatively related to the company's new capital investment, the results support the hypothesis 4 . Thus, for under-investment firms, the improvement of the accounting information quality can alleviate the under-investment of the firm, and for over-investment firms, the improvement of the accounting information quality can reduce the over-investment of the firm.

\subsection{Robustness Check}

In the robustness check, my measure of new investment expenditure is no longer from the cash flow statement, but from a balance sheet perspective, with "fixed assets and intangible assets at the end of this year minus those at the end of last year" as an alternative variable, And according to Hovakimian [17], I proxy for investment efficiency using the company's new investment expenditure minus the median of the industry companies. If the company's new investment expenditure is greater than the median value of the same industry, it will be classified into over-investment sample, otherwise it will be classified into under-investment sample. Under this classification, there are 2477 firms classified as under-investment firms and 2032 firms classified as over-investment firms. The robustness check of Table 5 shows that the results are similar. 
Table 4. Accounting information quality and future investment regressions.

\begin{tabular}{|c|c|c|c|c|c|c|}
\hline & \multicolumn{4}{|c|}{ Model 4} & \multirow{2}{*}{\multicolumn{2}{|c|}{ Model 5}} \\
\hline & \multicolumn{2}{|c|}{ Under-investment } & \multicolumn{2}{|c|}{ Over-investment } & & \\
\hline & (1) & (2) & (1) & (2) & (1) & (2) \\
\hline Intercept & $\begin{array}{l}-0.167^{* * *} \\
(-12.748)\end{array}$ & $\begin{array}{l}-0.137^{* * *} \\
(-10.122)\end{array}$ & $\begin{array}{l}-0.080^{*} \\
(-1.682)\end{array}$ & $\begin{array}{c}0.025 \\
(0.497)\end{array}$ & $\begin{array}{c}-0.164^{* * *} \\
(-6.652)\end{array}$ & $\begin{array}{c}-0.092^{* * *} \\
(-3.602)\end{array}$ \\
\hline $\mathrm{AQ}$ & $\begin{array}{c}0.035^{* * *} \\
(3.656)\end{array}$ & $\begin{array}{l}0.035^{* * *} \\
(3.698)\end{array}$ & $\begin{array}{c}-0.093^{* * * *} \\
(-2.631)\end{array}$ & $\begin{array}{l}-0.085^{* *} \\
(-2.430)\end{array}$ & $\begin{array}{l}0.140^{* * *} \\
(3.940)\end{array}$ & $\begin{array}{l}0.132^{* * *} \\
(3.749)\end{array}$ \\
\hline AQ*Partition & & & & & $\begin{array}{c}-0.376^{* * *} \\
(-5.639)\end{array}$ & $\begin{array}{c}-0.346^{* * *} \\
(-5.239)\end{array}$ \\
\hline Partition & & & & & $\begin{array}{c}0.037 \\
(5.872)\end{array}$ & $\begin{array}{l}0.031^{* * *} \\
(4.924)\end{array}$ \\
\hline Salesgrow & $\begin{array}{l}0.003^{* *} \\
(2.400)\end{array}$ & $\begin{array}{l}0.002^{* *} \\
(2.063)\end{array}$ & $\begin{array}{l}0.012^{* * *} \\
(3.909)\end{array}$ & $\begin{array}{l}0.010^{* * * *} \\
(3.300)\end{array}$ & $\begin{array}{l}0.009^{* * *} \\
(5.235)\end{array}$ & $\begin{array}{l}0.008^{* * * *} \\
(4.674)\end{array}$ \\
\hline Size & $\begin{array}{l}0.009^{* * *} \\
(14.963)\end{array}$ & $\begin{array}{l}0.007^{* * *} \\
(11.508)\end{array}$ & $\begin{array}{l}0.008^{* * *} \\
(3.670)\end{array}$ & $\begin{array}{c}0.002 \\
(0.791)\end{array}$ & $\begin{array}{l}0.008^{* * *} \\
(7.462)\end{array}$ & $\begin{array}{l}0.005^{* * *} \\
(3.991)\end{array}$ \\
\hline Age & $\begin{array}{c}-0.001^{* * *} \\
(-5.800)\end{array}$ & $\begin{array}{c}-0.001^{* * *} \\
(-5.144)\end{array}$ & $\begin{array}{c}-0.003^{* * *} \\
(-2.896)\end{array}$ & $\begin{array}{l}-0.002^{* *} \\
(-2.106)\end{array}$ & $\begin{array}{l}-0.001^{* *} \\
(-2.521)\end{array}$ & $\begin{array}{c}0.000^{*} \\
(-1.933)\end{array}$ \\
\hline Institutions & & $\begin{array}{l}0.104^{* * *} \\
(8.763)\end{array}$ & & $\begin{array}{l}0.240^{* * *} \\
(6.650)\end{array}$ & & $\begin{array}{c}0.224^{* * *} \\
(10.743)\end{array}$ \\
\hline Cont & & $\begin{array}{c}0.000 \\
(0.274)\end{array}$ & & $\begin{array}{c}0.003 \\
(0.596)\end{array}$ & & $\begin{array}{c}0.000 \\
(-0.324)\end{array}$ \\
\hline Sh1 & & $\begin{array}{l}0.014^{* * * *} \\
(3.503)\end{array}$ & & $\begin{array}{l}0.041^{* * *} \\
(2.853)\end{array}$ & & $\begin{array}{l}0.018^{* *} \\
(2.360)\end{array}$ \\
\hline $\mathrm{F}$ & 32.942 & 33.547 & 23.121 & 23.219 & 27.322 & 29.090 \\
\hline Adj- $R^{2}$ & 0.235 & 0.258 & 0.265 & 0.287 & 0.149 & 0.171 \\
\hline OBS & 2910 & 2910 & 1599 & 1599 & 4509 & 4509 \\
\hline
\end{tabular}

${ }^{* * * *},{ }^{* *}$ and ${ }^{*}$ denote significance at the $1 \%, 5 \%$ and $10 \%$ levels, respectively.

$\operatorname{Inv}_{\mathrm{i}, \mathrm{t}}=\varphi_{0}+\varphi_{1} \mathrm{AQ}_{\mathrm{i}, t-1}+\varphi_{2}$ Salesgrow $_{i, t-1}+\varphi_{3} \mathrm{Size}_{i, t-1}+\varphi_{4} \mathrm{Age}_{i, t-1}+\varphi_{5}$ Institutions $_{i, t-1}$

$+\varphi_{6}$ Cont $_{i, t-1}+\varphi_{7} \mathrm{Sh}_{i, t-1}+\varphi_{8} \sum$ Year Indicator $+\varphi_{9} \sum$ IndustryIndicator $+\varepsilon_{i, t} \quad$ (model 4);

$\operatorname{Inv}_{i, t}=\rho_{0}+\rho_{1} \mathrm{AQ}_{i, t-1}+\rho_{2} \mathrm{AQ} *$ Partition $_{i, t-1}+\rho_{3}$ Partition $_{i, t-1}+\rho_{4}$ Salesgrow $_{i, t-1}+\rho_{5}$ Size $_{i, t-1}+\rho_{6}$ Age $_{i, t-1}$ (model 5)

$+\rho_{7}$ Institutions $_{i, t-1}+\rho_{8} \mathrm{Sh}_{i, t-1}+\rho_{9} \sum$ Year Indicator $+\rho_{10} \sum$ Industry Indicator $+\varepsilon_{i, t}$

Table 5. Robustness check.

\begin{tabular}{|c|c|c|c|c|}
\hline & \multicolumn{2}{|c|}{ Under-investment } & \multicolumn{2}{|c|}{ Over-investment } \\
\hline & (1) & $(2)$ & (1) & $(2)$ \\
\hline Intercept & $\begin{array}{c}-0.227^{* * *} \\
(-7.331)\end{array}$ & $\begin{array}{c}-0.215^{* * *} \\
(-6.651)\end{array}$ & $\begin{array}{l}0.305^{* * *} \\
(4.642)\end{array}$ & $\begin{array}{l}0.369^{* * *} \\
(5.377)\end{array}$ \\
\hline AQ & $\begin{array}{l}0.112^{* * *} \\
(4.888)\end{array}$ & $\begin{array}{l}0.113^{* * *} \\
(4.937)\end{array}$ & $\begin{array}{l}-0.252^{* * *} \\
(-5.366)\end{array}$ & $\begin{array}{l}-0.252^{* *} \\
(-5.372)\end{array}$ \\
\hline Salesgrow & $\begin{array}{l}0.009^{* * *} \\
(4.105)\end{array}$ & $\begin{array}{l}0.009^{* * * *} \\
(3.893)\end{array}$ & $\begin{array}{c}0.005 \\
(1.155)\end{array}$ & $\begin{array}{c}0.005 \\
(0.997)\end{array}$ \\
\hline Size & $\begin{array}{l}0.008^{* * *} \\
(5.846)\end{array}$ & $\begin{array}{l}0.007^{* * * *} \\
(4.772)\end{array}$ & $\begin{array}{l}-0.014^{* * *} \\
(-4.746)\end{array}$ & $\begin{array}{l}-0.017^{* * *} \\
(-5.483)\end{array}$ \\
\hline Age & $\begin{array}{c}0.000 \\
(-0.772)\end{array}$ & $\begin{array}{c}0.000 \\
(-0.205)\end{array}$ & $\begin{array}{c}0.002 \\
(1.604)\end{array}$ & $\begin{array}{c}0.002 \\
(1.588)\end{array}$ \\
\hline Institution & & $\begin{array}{c}0.057^{*} \\
(1.787)\end{array}$ & & $\begin{array}{l}0.147^{* * *} \\
(3.088)\end{array}$ \\
\hline Cont & & $\begin{array}{c}-0.003 \\
(-0.999)\end{array}$ & & $\begin{array}{c}0.005 \\
(0.817)\end{array}$ \\
\hline Sh1 & & $\begin{array}{l}0.026^{* *} \\
(2.666)\end{array}$ & & $\begin{array}{c}0.006 \\
(0.331)\end{array}$ \\
\hline F & 9.991 & 9.366 & 13.139 & 12.188 \\
\hline Adj-R ${ }^{2}$ & 0.089 & 0.092 & 0.134 & 0.138 \\
\hline OBS & 2477 & 2477 & 2032 & 2032 \\
\hline
\end{tabular}

${ }^{* * *},{ }^{* *}$ and ${ }^{*}$ denote significance at the $1 \%, 5 \%$ and $10 \%$ levels, respectively.

$\operatorname{Inv}_{\mathrm{i}, \mathrm{t}}=\varphi_{0}+\varphi_{1} \mathrm{AQ}_{\mathrm{i}, \mathrm{t}-1}+\varphi_{2}$ Salesgrow $_{i, t-1}+\varphi_{3}$ Size $_{i, t-1}+\varphi_{4} \mathrm{Age}_{i, t-1}+\varphi_{5}$ Institutions $_{i, t-1}$

$+\varphi_{6}$ Cont $_{i, t-1}+\varphi_{7} \mathrm{Sh}_{i, t-1}+\varphi_{8} \sum$ Year Indicator $+\varphi_{9} \sum{\text { IndustryIndicator }+\varepsilon_{i, t}} \quad$ (model 4). 


\section{Conclusion}

This paper studies the relation between accounting information quality and investment efficiency. The empirical results show that the proxy for accounting information quality is negatively associated with the investment inefficiency. Furthermore, for under-investment (over-investment) firms, the accounting information quality is positively (negatively) related to the firm's future investment, that is, the improvement of the accounting information quality can alleviate the under-investment (over-investment) of the firm, suggesting that improving the quality of accounting information quality can improve the efficiency of capital allocation. This paper contributes to the literature that accounting information quality has economic consequences, so the market regulators should take measures to regulate the recognition and disclosure of accounting information, thus to improve corporate investment efficiency.

\section{Funding}

This work is supported by the Fundamental Research Funds for the Central Universities (0610-ZK1071).

\section{References}

[1] Biddle, G., Hilary, G. and Verdi, R.S. (2009) How Does Accounting Information Quality Relate to Investment Efficiency? Journal of Accounting and Economics, 48, 112-131. http://dx.doi.org/10.1016/j.jacceco.2009.09.001

[2] Biddle, G. and Hilary, G. (2006) Accounting Quality and Firm-Level Capital Investment. The Accounting Review, 5, 963-982. http://dx.doi.org/10.2308/accr.2006.81.5.963

[3] Modigliani, F. and Miller, M. (1958) The Cost of Capital, Corporation Finance, and the Theory of Investment. American Economic Review, 48, 261-297.

[4] Yoshikawa, H. (1980) On the “q” Theory of Investment. American Economic Review, 4, 739-743.

[5] Hayashi, F. (1982) Tobin’s Marginal q and Average q: A Neoclassical Interpretation. Econometrica, 50, $213-224$. http://dx.doi.org/10.2307/1912538

[6] Hubbard, G. (1998) Capital-Market Imperfections and Investment. Journal of Economic Literature, 36, $193-225$.

[7] Leuz, C. and Verrecchia, R. (2000) The Economic Consequences of Increased Disclosure. Journal of Accounting Research, 38, 91-124. http://dx.doi.org/10.2307/2672910

[8] Bushman, R. and Smith, A. (2001) Financial Accounting Information and Corporate Governance. Journal of Accounting Economics, 31, 37-333. http://dx.doi.org/10.1016/s0165-4101(01)00027-1

[9] Sun, J.L. (2005) Accounting Information Quality, Capital Allocation Efficiency and Financing Structure: An International Study. Ph.D. Dissertation, University of Corlrado.

[10] Cheng, M., Dhaliwal, D. and Zhang, Y. (2013) Does Investment Efficiency Improve after the Disclosure of Material Weaknesses in Internal Control over Financial Reporting. Journal of Accounting and Ecomomics, 56, 1-18. http://dx.doi.org/10.1016/j.jacceco.2013.03.001

[11] Lara, J.M.G., Osma, B.G. and Penalva, F. (2016) Accounting Conservatism and Firm Investment Efficiency. Journal of Accounting and Economics, 61, 221-238. http://dx.doi.org/10.1016/j.jacceco.2015.07.003

[12] Richardson, S. (2006) Over-Investment of Free Cash Flow. Review of Accounting Studies, 11, 159-189. http://dx.doi.org/10.1007/s11142-006-9012-1

[13] Dechow, P. and Dichev, I. (2002) The Quality of Accruals and Earnings: The Role of Accrual Estimation Errors. The Accounting Review, 77, 35-59. http://dx.doi.org/10.2308/accr.2002.77.s-1.35

[14] McNichols, M.F. and Stubben, S.R. (2008) Does Earnings Management Affect Firm’s Investment Decisions? The Accounting Review, 83, 1571-1603. http://dx.doi.org/10.2308/accr.2008.83.6.1571

[15] Ang, J.S., Cole, R. and Lin, J. (2000) Agency Costs and Ownership Structure. The Journal of Finance, 55, 81-106. http://dx.doi.org/10.1111/0022-1082.00201

[16] Ferreira, M. and Mators, M.P. (2008) The Colors of Investors' Money: The Role of Institutional Investors around the World. Journal of Financial Economics, 88, 499-533. http://dx.doi.org/10.1016/j.jfineco.2007.07.003

[17] Hovakimian, G. (2009) Determinants of Investment Cash Flow Sensitivity. Financial Management, 38, 161-183. http://dx.doi.org/10.1111/j.1755-053X.2009.01032.x 